Acta Universitatis Wratislaviensis • No 4046

Literatura i Kultura Popularna XXVI, Wrocław 2020

https://doi.org/10.19195/0867-7441.26.16

\title{
Hanna Dymel-Trzebiatowska
}

ORCID: 0000-0002-7753-5463

Uniwersytet Gdański

\section{O tym, jak dzieciom opowiedzieć o wszystkim. Moc metafory w norweskiej książce obrazkowej Blekkspruten Gro Dahle i Sveina Nyhusa}

Słowa kluczowe: książka obrazkowa, Gro Dahle, Svein Nyhus, tabu, kazirodztwo, metafora

Keywords: picture book, Gro Dahle, Svein Nyhus, taboo, incest, metaphor

Skandynawia to rejon, którego mieszkańcy w dialogu z dzieckiem nie stronią od tematów trudnych, egzystencjalnych, bolesnych. Autorzy książek dla dzieci i młodzieży, szczególnie tych ambitnych i nagradzanych, otwarcie mówią o samotności, starości, chorobach, bólu, rozwodach, śmierci... Tę otwartość na dyskusję z najmłodszymi można zinterpretować jako implikację światopoglądu skonstruowanego na fundamencie egalitaryzmu oraz szeroko pojętych idei równości i równouprawnienia. Również książka obrazkowa — gatunek literacki, który przez lata tradycyjnie był postrzegany jako skierowany do dzieci — nie uchyla się od podejmowania tematyki określanej jako kontrowersyjna bądź łamiąca kulturowe tabu, co nie umknęło obserwacji badaczy ${ }^{1}$. W książkach obrazkowych nie tylko chętnie omawiana jest śmierć wpisana w liczne dyskursy — ateistyczne, agnostyczne czy eschatologiczne ${ }^{2}$, ale też poruszane są zagadnienia, które w lite-

1 Zob. np. S. Beckett, Crossover Picturebooks. A Genre for All Ages, New York-London 2012; J. Evans, The legendary Klaus Flugge: Controversial picturebooks and their place in contemporary society, [w:] Challenging and Controversial. Creative and Critical Responses, red. J. Evans, New York-London 2015; A. Ommundsen, Who Are these Picturebooks for?, [w:] Challenging and Controversial...

2 Por. H. Dymel-Trzebiatowska, Niebo ma wiele imion. Śmierć w skandynawskich książkach obrazkowych, [w:] Śmierć w literaturze dziecięcej i młodzieżowej, red. K. Slany, Warszawa 2018, s. $147-170$. 
raturze dziecięcej wcześniej nie były obecne: choroby psychiczne, przemoc w rodzinie, ateizm, aborcja czy eutanazja. Wśród autorów tych nietypowych utworów powracają nazwiska dwóch norweskich twórców: Gro Dahle (autorki tekstów) oraz Sveina Nyhusa (ilustratora oraz autora tekstów). Para ta ma na swym artystycznym koncie wiele pięknych, obsypanych laurami książek, okrzykniętych zarówno literaturą ambitną, jak i niebanalną sztuką, która w przejmujący, maksymalnie eksplorujący potencjał ikonotekstu sposób konstruuje wewnętrzne światy dziecięcych bohaterów. Na polskim rynku jest kilka przekładów ich książek: opowieść tęskniącego za tatą Tomka (Pappa!, 1998; pol. Tato!, 2008); wyznania Emmy, samotnie zmagającej się z chorobą ukochanej mamy (Håret til mamma, 2007; Włosy mamy, 2010); feministyczna historia Lusi, która buntuje się przeciwko zamkniętemu w genderowych szablonach, niszczącemu jej tożsamość wychowaniu (Snill, 2002; Grzeczna, 2011); obraz losów Boja, który szuka ucieczki przed agresją brutalnego ojca (Sinna mann, 2003; Zły pan, 2013), oraz Ingi, samotnie stawiającej czoła rozwodowi rodziców (Krigen, 2013; Wojna, 2016) ${ }^{3}$.

Jak podkreśla Dahle, ich książki są przykładem literatury w języku norweskim nazywanej popularnym terminem allalderslitteratur (dla wszystkich grup wiekowych). Pisarka i zarazem poetka jest zagorzałą propagatorką tego określenia, które desygnuje coraz popularniejsze zjawisko dystansowania się wobec kategorii domyślnego czytelnika, z podkreśleniem walorów książki obrazkowej dla wszystkich:

W ten sposób [książka] otwiera się na językową zabawę i językowe eksperymenty w wielu wymiarach, ponieważ wszystko jest dozwolone, wszystko jest możliwe, dopóki jest to dobre, dopóki jest to interesujące, dopóki tekst dostarcza przeżyć również dziecku ${ }^{4}$.

Dahle uważa, że bogactwo ekspresywnego języka z zastosowaniem szerokiego spektrum figur stylistycznych (na przykład anafor, epifor, aliteracji) i licznych aluzji nie powinno działać zniechęcająco na najmłodszych, którzy nie zawsze muszą wszystko w pełni rozumieć. Nawet wówczas, gdy pewne elementy historii pozostają dla nich niedostępne, mogą bowiem wczuwać się w rytm języka, który wraz $\mathrm{z}$ obrazem kreuje magiczne przestrzenie stanowiące istotę książki obrazkowej.

Zgadza się z nią Svein Nyhus, który w wywiadach i na autorskiej stronie internetowej konsekwentnie określa swoje książki również jako allalderlitteratur i który powtarza opinię, że dzieciom można opowiedzieć o wszystkim, a ważny jest jedynie sposób, w jaki to się robi ${ }^{5}$. Już wcześniej mogliśmy słyszeć podobne słowa padające z ust Astrid Lindgren czy duńskiego artysty Oskara K., który dziś uchodzi za najbardziej kontrowersyjnego twórcę w przestrzeni skandynawskiej

${ }^{3}$ W książce Tato! autorem zarówno tekstu, jak i ilustracji jest Svein Nyhus, natomiast ilustratorką Wojny jest córka pary artystów — Kaia Dahle Nyhus.

4 G. Dahle, Bilderböcker som lekplats, [w:] En fanfar för bilderboken, red. U. Rhedin, K. Oscar, L. Eriksson, Stockholm 2013, s. 108. Fragment ten prezentuję we własnym przekładzie.

5 Informacja ze strony: http://sveinnyhus.blogspot.com/2016/09/blekkspruten-bildebok-om -seksuelle.html (dostęp: 18.01.2020). 
książki obrazkowej. W tej domenie Norwegowie i Duńczycy zdają się od pewnego czasu prześcigać w pomysłach i innowacjach, a o tym, że kolejne tematyczne tabu zostało złamane, świadczy utwór Dahle i Nyhusa z 2016 roku — Blekkspruten [Kałamarnica], który powstał przy współpracy artystów z Centrum Kazirodztwa z Vestfold.

Książki tej pary autorów często wykorzystywane są w kontekstach terapeutycznych, na przykład Zly pan został napisany na zlecenie terapeuty Øivinda Aschjema z norweskiej organizacji Alternatywa dla Przemocy. Nie są to jednak książki stricte instruktażowe, stworzone z myślą o pracy z psychologiem (choć oczywiście mogą być do tego wykorzystywane), ale zdecydowanie reprezentują literaturę piękną, otwartą na szerokie grono odbiorców. Autorzy — podobnie jak we wcześniejszych utworach — odnajdują w Blekkspruten sposób, aby w osnowę subtelnej werbalno-wizualnej narracji wpleść jeden z — zdawałoby się — najtrudniejszych tematów: gwałtu w rodzinie. Celem niniejszej analizy jest ukazanie owego sposobu, który sprawia, że norwescy artyści zdołali opowiedzieć o tak poważnym problemie w książce adresowanej również do małego dziecka. Jednocześnie chcę się zastanowić, w jakim stopniu utwór ten jest nowatorski w twórczości Dahle i Nyhusa, w jakim stanowi kontynuację konstrukcji fabularnej oraz estetyki ich wcześniejszych projektów. Tym samym spróbuję też wyjść naprzeciw postulatowi duńskiej ilustratorki Dorte Karrebæk, aby pracę ilustratorów postrzegać jako continuum, ponieważ takie podejście jest praktycznie nieobecne w badaniach książki obrazkowej ${ }^{6}$.

Metaforyka Blekkspruten opiera się przede wszystkim na paralelach w charakterystyce ludzi i zwierząt. Już pierwsze otwarcie pozwala nam zapoznać się z protagonistką, małą Gullet [Złotko] $]^{7}$, która w komunikacie werbalnym przedstawiona jest $\mathrm{w}$ tendencyjnie przesłodzonym tonie - jako iskrząca grudka złota, która, jak mówi mama, błyszczy nawet, gdy bawi się swoimi zwierzątkami. W tym krótkim fragmencie tekstu na pierwszej stronie książki owe określenia: złoto, złotko, grudka złota padają wielokrotnie w odniesieniu do dziewczynki, podkreślając emocjonalny, nieco infantylny stosunek rodziców do idealizowanej, niewinnej córeczki. W sumie tekst nie wnosi na tym etapie zbyt wielu informacji, a ich potężnym nośnikiem - w wyraźnie dopowiadającej relacji — staje się wykonany przez Sveina Nyhusa obraz.

Lewa strona zintegrowanej na rozkładówce spadowej ilustracji przedstawia postać kilkulatki bawiącej się na podłodze licznymi zabawkami. Są to zwierzęta różnych gatunków: od egzotycznych słoni, tygrysów i żyraf, przez niedźwiedzie i byki, po strusie i kury. Nad dziewczynką górują, w charakterystycznym dla artysty stylu, wysokie postaci mamy i taty. Ich wzrost i proporcje w odniesieniu do małej Gullet wskazują na relacje władzy, co cechowało również obrazowanie

${ }^{6}$ D. Karrebæk, K. Oscar, Världen rinner bort, [w:] En fanfar för bilderboken..., s. 65-79.

${ }^{7}$ Gdy piszę ten artykuł, książka nie została przetłumaczona na język polski i dlatego posługuję się własnymi przekładami. 
dzieci i dorosłych we wcześniejszych książkach, na przykład Tato!, Włosy mamy, Grzeczna i Zly pan ${ }^{8}$. Szczegól, który je różni, to kształty rodziców - rysowani dotąd zazwyczaj krągłą linią o jednolitych konturach, upodabniającą ich do nadętych balonów, stają się teraz smukli i ,stożkowaci”. Zdecydowaną kreskę zastąpiła natomiast niepewna, „szarpana”, jakby kilkukrotnie poprawiana linia. Gabaryty rodziców dodatkowo podkreśla ich postawa - aby zmieścić się na rozkładówce, muszą być przesadnie, niemal pod kątem prostym przygarbieni. W przypadku taty pozycję tę dodatkowo wymusza jego nieodłączny, ,niemy” atrybut — telefon komórkowy, w który wciąż się wpatruje, a który będzie mu towarzyszył na kolejnych ilustracjach. Ponadto rodzic ma w uszach słuchawki i poprzez tę formę izolacji od rodzinnego otoczenia przypomina tatę Lusi z Grzecznej, którego zakrywała potężna gazeta. W tym szczególe, już na samym początku, obraz staje w relacji kontrapunktowej do przekazu tekstowego, według którego Gullet jest „złotkiem tatusia”. Po raz kolejny ojcowie w grze słów i ilustracji przedstawieni są jako egoistyczni hipokryci, którzy własne zainteresowania stawiają ponad swoje dzieci.

Paletę barw zdominowały dwa stonowane kolory — odcienie żółci i szarości, którymi ilustrator zdaje się malować obrazy podszyte wyraźną symboliką. Przedstawiona po lewej stronie Gullet otoczona jest zamkniętą w złotych konturach żółcią, korespondującą z jej ,świetlistą" aurą, na przełomie zaś stron zaczyna przenikać szarość - w tej strefie sytuuje się sylwetka mamy — aby dalej zdominować prawą stronę. To tu, w owej „ciemnej” przestrzeni, znajduje się postać taty oraz dodatkowy członek rodziny, o którym milczy tekst. Widzimy bowiem leżącego na sofie w nonszalanckiej pozie nastolatka, który trzyma w dłoniach iPada, a w uszach - podobnie jak ojciec - ma słuchawki. Ta pozornie sielankowa, rodzinna scena nosi pewne znamiona niepokoju, antycypujące tragiczny rozwój wydarzeń. Wyraża je wyłącznie wizualna reprezentacja — podobnie jak we wcześniejszych książkach ilustrowanych przez Nyhusa, w których pojawiały się często ostre, niepasujące do bezpiecznych wnętrz przedmioty, rozrzucone puzzle i wyłączone z kontaktów wtyczki od lamp (Tato!, Włosy mamy, Zły pan). Tu z kolei złowieszczo wygląda końcówka paska od spodni, zwisająca pomiędzy udami chłopaka, stojąca na podłodze przy sofie rolka papieru, otwarte drzwi do toalety oraz wyraźne zarysowane organy płciowe zabawek, którymi bawi się Gullet.

Kolejna rozkładówka podąża symbolicznie zwierzęcym tropem tej skrupulatnie zaplanowanej ikonotekstowej narracji. Gullet bawi się z rodziną: tato ma być strusiem, a brat małpą — tak nazywa go czasem mama, gdy niechlujnie je, i pod takim imieniem znamy go w tej części historii. Tekst przekazuje, że tato nie chce się bawić, natomiast Małpa jest ulubionym towarzyszem zabaw dziewczynki i często

${ }^{8} \mathrm{Na}$ charakterystyczną dysproporcję w rozmiarach dorosłych i dzieci zwracają uwagę również inni badacze, na przykład A.M. Bjorvand, Do Sons Inherit the Sins of Their Fathers? An Analysis of the Picturebook Angry Man, [w:] New Directions in Picturebook Research, red. T. Colomer, B. Kümmerling-Meibauer, C. Silva-Diaz Cecilia, New York-London 2010, s. 205-232; i S. Beckett, op. cit. 
ją rozśmiesza. Ponownie to ilustracja będzie w tej scenie nośnikiem większości informacji — jej centralna część zdominowana jest przez sylwetkę brata, który niczym małpa idzie na czworakach, a na jego plecach siedzi radosna, śmiejąca się Gullet. Twarz chłopca, znów z dużymi słuchawkami w uszach i niedopiętym paskiem u spodni, wykrzywia grymas, a jego przednie kończyny nienaturalnie się wyginają. Po prawej stronie widzimy ubraną do wyjścia, stojącą przy drzwiach mamę, $w$ tle zaś siedzącego na sofie $\mathrm{z}$ telefonem $\mathrm{w}$ dłoni ojca. I tym razem barwy zostają przydzielone bohaterom według wydaje się nieprzypadkowego klucza: postaciom kobiecym towarzyszy złoto i sepia, natomiast męskim — popiel.

Trzecie otwarcie rozpoczyna kontynuowaną na kolejnych sześciu rozkładówkach tragedię. Jej jedynymi aktorami będą: mała Gullet i jej brat Małpa. Chłopiec, nienaturalnie szybko dysząc, staje $\mathrm{w}$ drzwiach pokoju i z powagą wpatruje się w bawiącą się na podłodze siostrę, która nie rozumie jego zachowania. Potem brat zamyka drzwi na klucz i zaciąga zasłony. Jego wizualizacja zmienia się, kończyny i szyja nienaturalnie się wydłużają i zaginają. Gdy chłopiec mówi, że będą się bawić w kałamarnicę, a jego zimne i wilgotne dłonie-macki dotykają dziewczynki, ta nie jest pewna, co ma myśleć: „Gullet robi się sztywna, nie może się ruszyć, nie może wypowiedzieć ani słowa" (otwarcie 5). W tym miejscu na ilustracji widzimy wielką ludzką głowę z pięcioma potężnymi odnogami, która przybliża się do małej dziewczęcej postaci. Rozkładówkę zalewa szarość, spod której w zaledwie kilku miejscach przebija blady odcień złota.

Gdy kałamarnica każe dziewczynce zdjąć spodnie, ta z początku się nie zgadza. Po chwili jednak ulega, ponieważ nie umie się sprzeciwić kałamarnicy i nie ma odwagi głośno powiedzieć „nie”. Tę scenę ilustruje stojąca tyłem naga sylwetka dziewczynki, do której zbliżają się potężne macki potwora. Nie ma w nim już żadnych pozostałości człowieka, a pomiędzy jego odnogami wirują w nieładzie części garderoby Gullet. Gdy kałamarnica wytryskuje atramentem, bohaterka wie, że nie ma drogi ucieczki, ponieważ widziała filmy w telewizji ukazujące atak głowonogów. Na ilustracji pojawia się nowy kolor, wirujący obłok czerni, który przybliża się do przestraszonej, trzymanej w splocie macek dziewczynki.

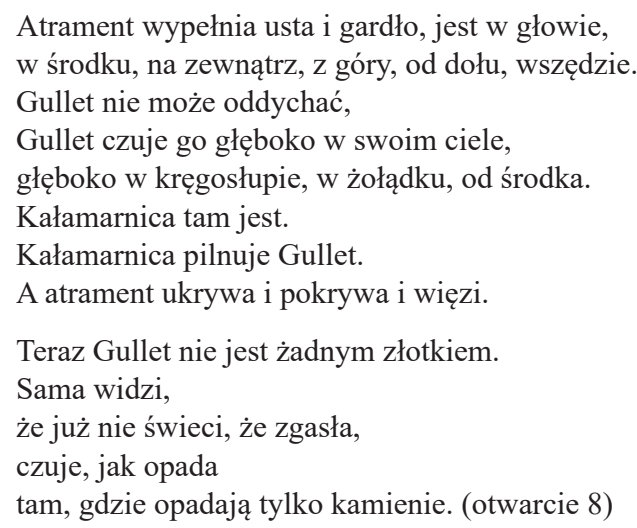


Temu symbolicznemu tekstowi towarzyszy wymowna ilustracja, która jednak nie wizualizuje słów, lecz chwilę po tym, co się właśnie wydarzyło: na lewej stronie, pokrytej szarością z ciemniejszą plamą — pozostałością po wizycie „gościa" - widzimy plecy małej, kucającej w lewym dolnym rogu postaci. Jest naga i obejmuje się ramionami. Na prawej stronie ukazany jest pokój Gullet, z porozrzucanymi ubraniami i kartonami zabawek, oraz zamykające się drzwi, którymi wychodzą ostatnie odnogi kałamarnicy.

Odtąd ciało Gullet drży i pulsuje. Dziewczynka wie, że już nigdy nie pozbędzie się Kałamarnicy (brat symbolicznie zmienia imię), ponieważ jest w domu, w pokoju, w jej głowie i zachowuje się, jakby nic się nie stało. Ilustracja po lewej stronie rozkładówki przedstawia skuloną, przestraszoną bohaterkę ściskającą przytulanki i otoczoną szarością, podczas gdy prawa ukazuje wykrzywionego w uśmiechu leżącego na sofie brata. Jest wyraźnie usatysfakcjonowany, pewny siebie i swej bezkarności, a jego nastrój tym razem odzwierciedla żółty kolor. Podobnie jak wcześniej na uszach ma duże słuchawki, na spodniach nieustannie zwisający pasek, a na biodrach iPada. Wokół niego na podłodze leżą brudne naczynia, rozwinięta rolka papieru toaletowego i rzucona skórka banana, która upadła tak, że kształtem przypomina małą kałamarnicę. Do wcześniejszej inkarnacji chłopca na tym wizerunku nawiązuje jego nienaturalnie wyciągnięta prawa ręka, której długość symbolicznie sugeruje wciąż aktualne zagrożenie dla siostry. $\mathrm{Z}$ ironiczną postawą bohatera współgra nienaturalna perspektywa tej sceny talerze i iPad narysowane są tak, że zdają się patrzeć prosto na nas, natomiast klucz do pokoju Gullet wydaje się „wisieć” w powietrzu. Nic nie jest tak, jak być powinno, a jednak nic się nie dzieje.

Trzy kolejne otwarcia opowiadają o wewnętrznych zmaganiach bohaterki. Rodzice dopytują, dlaczego milczy, a ona czuje, że nie jest już ich „złotkiem”, że przemieniła się w ciemny podwodny kamień. Zastanawia się, czy nie opowiedzieć wszystkiego mamie, której spojrzenie daje jej poczucie bezpieczeństwa, jednak wciąż brakuje jej odwagi: „Może mama pomyśli, że kłamie. A może ona kłamie. Może to wszystko nieprawda" (otwarcie 11). Dziewczynka ma coraz więcej wątpliwości i zastanawia się, czy to ona jest winna temu, co się wydarzyło, i czy to nie ona zaczęła tę zabawę. Wini też swoje ciało, które ją zdradziło:

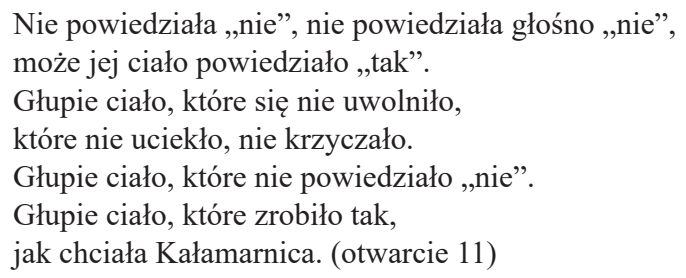

Dopiero wspólna przejażdżka autem z mamą za miasto sprawia, że dziewczynka się otwiera. Samochód jest bezpieczny i Gullet czuje, że nie ma w nim już atramentu Kałamarnicy, zaczyna opowieść od pojedynczych słów, aby wkrót- 
ce wszystko wyjawić. Na ilustracji kabinę auta znów rozświetla złota poświata, a w tle symbolicznie góruje rozpromienione słońce. Gdy dziewczynka wciąż nie ma pewności, czy słusznie postąpiła, padają kluczowe dla terapeutycznego wymiaru opowieści słowa:

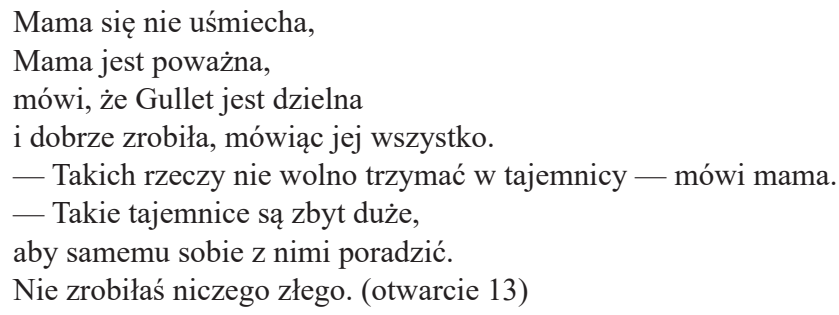

Mama, która jest teraz bardzo zła na Kałamarnicę, symbolicznie przeistacza się w orła. Nie dowiemy się, czy brat został ukarany. Dowiemy się natomiast, że tato jak struś chowa głowę w piasek, a opiekuńcza mama odbywa wiele długich rozmów telefonicznych. Potem Gullet musi spędzić dużo czasu poza domem, opowiadać i odpowiadać na pytania, a każdy dorosły zapewnia ją, że postąpiła słusznie. Wszystkie te informacje pochodzą z przekazu werbalnego, uzupełnionego obrazami dziewczynki, do której wizerunku wracają złote barwy i której teraz nieustannie towarzyszy mama. Ze stron książki płynie wyraźny przekaz — to dorośli muszą pomagać dzieciom w takich sytuacjach.

Nie jest to jednak opowieść o kazirodczym gwałcie opowiedziana w czarno-białych kolorach. Gdy mama pyta córkę o brata, ta przyznaje, że trochę za nim tęskni. Chłopiec nie opuścił domu i choć tekst nie przekazuje nam o nim żadnej informacji, ilustracja w pełni je dopowiada. Postać Małpy/Kałamarnicy siedzi na krześle ze spuszczoną głową, i choć znów otoczona jest szarością, to daleko jej do wcześniejszej nonszalanckiej pozy na sofie. Nie towarzyszą jej też iPad i słuchawki, a pasek u spodni jest starannie zapięty.

Gullet odzyskuje poczucie bezpieczeństwa i wiarę w ludzi, co uosabia przedostatnie otwarcie, na którym dziewczynka wraz z mamą znajduje się na thumnej plaży. Jest na niej wiele dzieci bawiących się z dorosłymi, czemu dziewczynka przygląda się, siedząc bezpiecznie przy mamie.

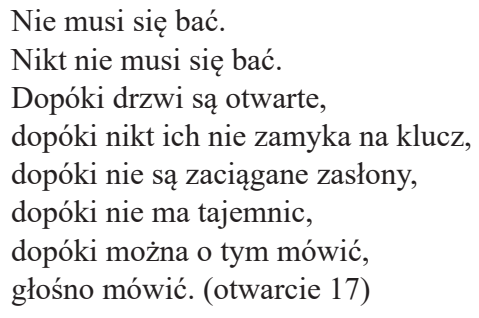

Ostatnia rozkładówka zawiera wiele sygnałów, które pozwalają zinterpretować ją jako szczęśliwe zakończenie. Podobnie jak na pierwszym otwarciu widzimy na niej pełną rodzinę, a kompozycyjną klamrę tworzą w niej analogicz- 
ne zwroty, które padły na początku — rodzice nazywają córeczkę złotkiem, a ta czuje, że zaczyna błyszczeć i świecić. Czytamy, że w końcu czuje się bezpieczna w swoim domu i pokoju oraz że czekają ją nowe dni, kiedy będzie mogła się bawić, spać i marzyć.

Jak zwykle obraz dopowiada tu wiele szczegółów, a w kilku miejscach stawia małe znaki zapytania. Gullet na prawej stronie rozkładówki siedzi i rysuje przy stole, a nad nią góruje duża postać mamy, która obejmuje córkę za szyję. Drugim ramieniem mama obejmuje męża, który wraz z synem przedstawieni są na lewej stronie $\mathrm{w}$ tradycyjnym kolorystycznym podziale — panie w jasnych, żółtych barwach, panowie - szarych i mrocznych. Tato siedzi na sofie, obejmując prawą ręką syna, co w tym symbolicznym „łańcuchu dotyku” wyraża rodzinną więź, a zarazem ukazuje, że wszyscy nadal są wspólnotą. Chłopiec zaprezentowany jest w zupełnie inny niż dotąd sposób - jest mały i przykryty kocem, znad którego widać jedynie pozbawioną wyrazu twarz z dużymi czarnymi oczodołami. Jest pusta i daleka od złośliwego samozadowolenia, które wcześniej z niej promieniowało. W pokoju nadal rozrzucone są zwierzątka-zabawki, a w rogu sofy leżą telefon, iPad oraz splątane słuchawki. Nikt ich jednak teraz nie używa, a na kolanach taty leży rozłożona książka. Owe znaki zapytania, które stawia przed czytelnikiem wizualizacja finalnej sceny, to przede wszystkim twarz chłopca, o którym tekst całkowicie milczy. Obraz, dając wyraźnie do zrozumienia, że brat Gullet jest smutny, odmieniony, niesie też pewien niepokój i niepewność, czy twarz wyraża chorobę, farmakoterapię czy może strach... Z jednej strony drobne elementy wnętrza - otwarta szuflada oraz otwarty kuferek na oknie — dają symbolicznie do zrozumienia, że w tym domu i w tej rodzinie nie ma już tajemnic. $Z$ drugiej siedząca na pierwszym planie postać małej małpki ma naciągniętą na oczy czapkę oraz plaster na ustach. Czy zatem nie wszystko zostało powiedziane i na niektóre sprawy wciąż przymyka się oczy?

Te niedopowiedzenia to cechy typowe dla stylu Sveina Nyhusa. Jak sam pisze na swojej autorskiej stronie - chce tworzyć obrazy wieloznaczne, mogące być wyzwaniem dla tych, którym wydaje się, że zawsze wszystko muszą zrozumieć ${ }^{9}$. Dlatego wizualne zakończenie Blekkspruten nie jest równie optymistyczne jak jego tekstowy wariant — tak samo jak w Zlym panu, w którym pojednanie Boja z ojcem w kilku miejscach zdaje się na ilustracji wyraźnie zakwestionowane. Norweska badaczka Agnes-Margrethe Bjorvand zwraca uwagę na czerwone dłonie taty, które również charakteryzują samego Boja. Ta dziedziczna cecha, sugerująca skłonność do przemocy, nie znika w przestrzeni ikonotekstu całej opowieści i podważa jej bajkowe, optymistyczne zakończenie. Bjorvand odczytuje ostatnią rozkładówkę Złego pana jedynie jako wizję Boja, a nie autentyczne przeżycie,

9 Informacja ze strony internetowej: http://sveinnyhus.blogspot.com/2016/09/blekksprutenbildebok-om-seksuelle.html (dostęp: 19.01.2020). 
którego iluzoryczność akcentuje fakt, że podobna scena rozgrywała się w Tacie!, gdzie Tomek od początku do końca oddaje się katartycznym fantazjom ${ }^{10}$.

Podważenie werbalnego szczęśliwego zakończenia przez ilustracje nie jest jedyną referencją do wcześniejszych utworów norweskich artystów. Sama konstrukcja fabularna Blekkspruten zawiera wiele paraleli do Złego pana - uciśnione dziecko, które skrywa rodzinną tajemnicę, musi zdobyć się na odwagę, aby podzielić się nią ze światem i wówczas może liczyć na wsparcie oraz pomoc w rozwiązaniu problemu. Oczywiście diametralnie inne są przyczyny zniewolenia - choroba alkoholowa oraz kazirodczy stosunek — jednak tragedie nadal rozgrywają się w bardzo podobnym — rodzinnym, domowym — środowisku. To ono, niczym zamknięta klatka, sprzyja kultywowaniu autodestrukcyjnej tajemnicy, a dopiero wyjście poza dom, w naturę niesie ozdrowieńczą zmianę. Ten motyw, o którym pisze w swoich badaniach Atle Krogstad ${ }^{11}$, powraca i tu — dopiero gdy Gullet udaje się z mamą na przejażdżkę samochodem poza miasto, znajduje odwagę, aby podzielić się swoją tajemnicą, z kolei jej zaufanie w dobroć i w człowieka powraca na plaży.

Ponadto w książkach Dahle i Nyhusa często w tle głównej opowieści, wśród elementów wizualnego tła, rozgrywają się „nieme” historie, symbolicznie współbrzmiące z fabułą, które w anglojęzycznej teorii książki obrazkowej zyskały nazwę running story ${ }^{12}$ lub syllepsis ${ }^{13}$. W autorskim utworze Sveina Nyhusa Tato! bohaterką równoległej minifabuły jest małpka Tomka, która towarzyszy mu na każdej rozkładówce. Jest jego nierozłączną przyjaciółką, dając do zrozumienia, że koi go w samotności. Chłopiec na większości ilustracji ukazany jest z nią w objęciach i tylko w kilku scenach, gdy jego zabawy z wyimaginowanym ojcem nabierają tempa, przytulanka zaczyna żyć własnym życiem — przysypia w kącie lub gra na komputerze. Jest wyraźnie antropomorficzna, duża i krągła, wpisując się tym w estetykę książki, w której przeważają zaokrąglone linie i kształty.

W Blekkspruten wśród zwierzątek-zabawek małej Gullet również znajdują się małpki. Są jednak rysowane zupełnie inną kreską i przypisane są im inne role. Ich obecność nie jest też tak wyraźnie zaakcentowana jak pokaźnych rozmiarów małpki Tomka - są znacznie mniejsze i pojawiają się tylko na kilku rozkładówkach. Rysowane są tą samą „niepewną” linią co pozostałe zabawki i w pierwszym otwarciu widzimy je dwukrotnie. Jedna z nich, po lewej stronie ilustracji, z zarysowanym organem płciowym między nogami, wpisuje się w antycypowany libidalny zwrot akcji. Z kolei goryl w lewym dolnym rogu, poniżej sofy, na której wyleguje się brat, ma nieprzyjemny wyraz pyska i jest uosobieniem bezmyślnej siły.

10 A.M. Bjorvand, op. cit., s. 230.

11 A. Krogstad, The family house chronotope in three picturebooks by Gro Dahle and Svein Nyhus: idyll, fantasy, and threshold experiences, „Barnelitterært Forskningstidsskrift” 2016, nr 7.

12 J. Doonan, Looking at Pictures in Picturebooks, Stround 1993.

13 M. Nikolajeva, C. Scott, How Picturebooks Work, New York-London 2006. 
Motyw małpki powraca w kulminacyjnym punkcie, podczas „ataku Kałamarnicy" (otwarcie 6), kiedy na ilustracji wśród wirujących macek potwora widzimy unoszące się w odmętach „wody” części garderoby Gullet oraz surfującą na kluczu małpkę. Jest odwrócona tyłem do rozgrywającej się sceny i zasłania łapkami pyszczek w geście szoku. Jest też obecna na następnej rozkładówce, gdy sparaliżowana dziewczynka wciąż czuje w domu zagrożenie — na sofie widzimy leżącego zadowolonego brata, a z boku małpkę w szerokim rozkroku z bardzo długim ogonem-przyrodzeniem między nogami. Jej udział w fabule jest szczególnie wymowny na wspomnianej już finalnej rozkładówce, gdy nie widząc i nie mówiąc, sugeruje obecność dalszych tajemnic w rodzinie Gullet.

Inny element wizualnej narracji, który powraca w Blekkspruten, to klucz. Jest on również obecny w Tacie!, gdzie otwiera tajemniczy kuferek, który występuje na większości rozkładówek. Na początku, w pierwszym otwarciu, jest włożony do jego zamka, potem ów kuferek jest otwarty, a klucz znika, aby powrócić na końcu — w scenie szalonej zabawy z tatą Tomek trzyma go w dłoni, a na ostatniej stronie klucz leży samotnie na podłodze, podczas gdy kuferek znów stoi szczelnie zamknięty na parapecie okna.

Szafy, kuferki i szkatułki mają interesujące, symboliczne znaczenie w konstruowaniu światów przedstawionych i ich symbolika — otwarcia bądź zamknięcia - przybliża nas lub oddala od wewnętrznych światów bohaterów ${ }^{14}$. W historii Boja klucz powraca $\mathrm{w}$ innej roli — jest dosłownie wyjściem z wnętrza domu, metaforycznie zaś - wyjściem z wydawałoby się patowej sytuacji i zarówno jest o nim mowa w tekście, jak i widać go na ilustracjach ${ }^{15}$. Dosłowną i metaforyczną rolę odgrywa również w Blekkspruten, gdzie z kolei zamyka drzwi. Klucz jest symbolem nie wyzwolenia, ale opresji. To nim Małpa/Kałamarnica zamyka drzwi pokoju Gullet i to on powraca w tle wielu ilustracji, zarówno przepowiadając to, co się wydarzy, jak i przypominając o tym, co już zaszło. Nie znika nawet z ostatniej rozkładówki, gdy leży na sofie obok elektronicznych zabawek taty i brata i może być odczytany jako kolejny ikonograficzny znak podający w wątpliwość sygnalizowane przez tekst rozwiązanie problemu. O jego znaczeniu świadczy też fakt, że to właśnie on znalazł się na stronie tytułowej, jako jedyny — w domyśle: niepozbawiony znaczenia - element, poza samym napisem Blekkspruten.

Kolejny komponent wykorzystywany przez Sveina Nuhusa w kreowaniu atmosfery niepewności i zagrożenia to niebezpieczne przedmioty, które artysta sytuuje w wielu zaskakujących, nieadekwatnych do ich funkcji miejscach. W książce Tato!, która pozornie snuje fantastyczną opowieść Tomka o idealnym ojcu, podczas wizualizacji zabaw na podłodze pojawiają się znienacka noże-piły,

14 Por. G. Bachelard, Poetyka przestrzeni: szuflada, kufry i szafy, przeł. W. Krzemień, „Pamiętnik Literacki" 1976, z. 1, s. 233-243.

15 Por. H. Dymel-Trzebiatowska, "Talking containers". Visual heterotopias in the picturebooks illustrated by Svein Nyhus, „Folia Scandinavica Posnaniensia” 2018, nr 25, s. 76-88. 
pinezki, zapałki, ostrogi, drut kolczasty... Wielkie noże i nożyczki często występują we wnętrzach domu Emmy we Włosach mamy, a w mieszkaniu Boja w Złym panu już na pierwszej rozkładówce tapeta ma wzór ognistych płomieni, młotek leży tuż obok szklanego akwarium, a miska z rodzynkami stoi na skraju stołu. W Blekkspruten owe przedmioty w przeważającej części zastąpił motyw zabawek-zwierzątek, jednak nie znikły one całkowicie. Gdy tuż po ataku Kałamarnicy Gullet przeżywa chwile zwątpienia i grozy, w tle pojawiają się ogromne nożyczki (otwarcie 9) oraz skierowany ku temperówce naostrzony ołówek (otwarcie 10).

W Blekkspruten, podobnie jak w innych wspomnianych tekstach Gro Dahle, występuje ten sam rodzaj narracji. Werbalną historię snuje intra-heterodiegetyczny narrator, który tak mocno fokalizuje małego protagonistę, że można odnieść wrażenie, iż to on(a) sam(a) nam ją opowiada. Poznajemy jego myśli, uczucia, postrzegamy sytuację przefiltrowaną przez jego/jej zmysły. Jest to ciekawe rozwiązanie, ponieważ z jednej strony gwarantuje wysoki stopień empatii z bohaterem, $z$ drugiej - nie wyklucza jego wizualnej reprezentacji. Przy wyborze autodiegetycznego narratora zgodność perspektywy wizualnej z werbalną oznaczałaby, że czytelnik/obserwator musiałby widzieć wszystko jego oczami, nie widząc jego samego. $\mathrm{Z}$ kolei pierwszoosobowa narracja $\mathrm{w}$ tekście wraz $\mathrm{z}$ jednoczesnym ukazaniem bohatera $\mathrm{z}$ innej perspektywy mogłyby zakłócać percepcję ikonotekstu ${ }^{16}$. Takie rozwiązanie byłoby problematyczne, szczególnie dla dzieci, które nadal są odbiorcami tej wieloadresowej literatury, i dlatego narracja Dahle doskonale się tu sprawdza. Na ilustracjach widzimy Tomka, Boja, Emmę, Lusię lub Gullet, a jednocześnie, czytając tekst, czujemy tak jak oni. Narracja wizualna jest jednak bardziej skomplikowana, widzimy bowiem nie tylko oczami intra-heterodiegetycznego obserwatora, ale jednocześnie postrzegamy symboliczne obrazy, które najwyraźniej są elementami wewnętrznego świata protagonisty, przybierając cechy narracji autodiegetycznej. Tato Boja przeobrażony w trolla, jego fruwająca niczym anioł mama czy brat Gullet, który bawiąc się w kałamarnicę, staje się nią, są tym, co widzą i czują dziecięcy bohaterowie tych opowieści. Jest to intrygujący sposób opowiadania obrazem, ponieważ te pozornie niekompatybilne punkty widzenia sprawnie się splatają, wzbogacając opowieść.

Z perspektywy wcześniejszej twórczości duetu Dahle-Nyhus nie dziwi, że i w Blekkspruten głównym oraz najsilniejszym środkiem ekspresji jest metafora. Choć jej odmianę wykorzystaną w tym utworze można zdecydowanie potraktować jako środek wyobraźni poetyckiej, warto spojrzeć na powszechniejszą funkcję metafor, przypisywaną im przez językoznawców kognitywnych, odnajdujących ich obecność nie tylko w języku, ale też w ludzkich myślach i postępowaniu. Mimo że system pojęć jest czymś, co traktujemy automatycznie i nie poświęcamy mu zbyt wiele refleksji, odgrywa on w naszym życiu fundamentalną rolę:

16 M. Nikolajeva, C. Scott, op. cit., s. 125. 
Pojęcia, które kierują naszym myśleniem, nie są jedynie sprawą intelektu. Kierują także naszym codziennym postępowaniem, nie wykluczając nawet najbardziej przyziemnych szczegółów. Pojęcia te nadają kształt temu, co postrzegamy, temu, jak dajemy sobie radę w otaczającym nas świecie i jak odnosimy się do innych ludzi. W ten sposób nasz system pojęć odgrywa główną rolę w określaniu naszej codziennej rzeczywistości. Jeżeli prawdą jest, że nasz system pojęć ma w głównej mierze charakter metaforyczny, to wówczas sposób, w jaki myślimy, to, czego doświadczamy i co czynimy na co dzień, jest w wielkiej mierze sprawą metafory ${ }^{17}$.

Jeśli założymy, że ludzkie porozumienie opiera się na wspólnym systemie pojęciowym nasyconym metaforami konwencjonalnymi, to implikacją tego stanu jest gotowość odczytania bardziej skomplikowanych metafor poetyckich. Co więcej, nie jest ona zarezerwowana dla osób oczytanych i zaznajomionych z poetyką, ale też na przykład dla dzieci, które zaczynają dzielić z otoczeniem pojęcia i wypracowywać wyobraźnię metaforyczną, coraz lepiej rozumiejąc oraz coraz częściej doświadczając pewnych rzeczy w terminach innych rzeczy. Są w stanie zrozumieć na przykład wędrówkę Emmy w gąszczu włosów mamy, zniknięcie w ścianie Lusi czy atakującą Gullet kałamarnicę. Metaforę można zatem uznać za wspólny mianownik obrazkowej literatury Dahle i Nyhusa, a także za odpowiedź na pytanie o ich sukcesy. Niewątpliwie jest pewną, powtarzającą się metodą twórczą tych artystów, ale dzięki swej specyficznej naturze nie staje się wtórna i nie nuży.

W Blekkspruten powtarza się też ten sam co we wcześniejszych utworach typ intra-heterodiegetycznej, przesyconej figurami retorycznymi werbalnej narracji, która dzięki mocnej wewnętrznej fokalizacji dziecięcych protagonistów i współbrzmieniu z perspektywą wizualną doskonale wykorzystuje potencjał ikonotekstowej opowieści. Ponieważ Nyhus wyraźnie chce zachować pewną interwizualną więź pomiędzy swoimi utworami, obecność powracających elementów reprezentacji wnętrz na jego ilustracjach nie jest żadnym rewelacyjnym odkryciem. Warto jednak zwrócić uwagę na ich ewolucję i metamorfozy. We wcześniejszych książkach artysty (na przykład Tato!, Włosy mamy, Zły pan) powracały zagubione na podłodze puzzle, sugerujące niemożność stworzenia pełnego i gotowego obrazu. Tym razem ilustrator już ich nie wykorzystuje, nie rezygnując jednak z ostrych przedmiotów, motywu małpki, a nade wszystko klucza, który jest ważnym elementem symboliki w historii Gullet, choć z inną niż we wcześniejszych utworach funkcją. Coraz częściej sięga po symbole, ogranicza paletę barw i zmienia kreskę, nieustannie dając czytelnikom do zrozumienia, że nie sposób udzielić odpowiedzi na wszystkie pytania.

Blekkspruten na pewno jest ważną i pomocną w edukacji prewencyjnej książką, która wskazuje na istotę otwartej rozmowy z dorosłym. Choć zaprezentowana w niej ikonotekstowa opowieść o kazirodztwie bez wątpienia jest pełna emocji i bólu, to można ją bezpiecznie wykorzystać w dialogu z dzieckiem dzięki werbalnym i wizualnym metaforom, ukazanym w splocie kilku perspektyw wypracowanych przez parę doświadczonych artystów.

17 G. Lakoff, M. Johnson, Metafory z naszym życiu, przeł. T.P. Krzeszowski, Warszawa 2010, s. 29. 


\section{Bibliografia}

\section{Teksty źródłowe}

Dahle G., Dahle Nyhus L., Krigen, Cappelan Damm, Olso 2013.

Dahle G., Nyhus S., Blekkspruten, Cappelan Damm, Oslo 2016.

Dahle G., Nyhus S., Grzeczna, przeł. H. Garczyńska, EneDueRabe, Gdańsk 2011.

Dahle G., Nyhus S., Håret til mamma, Cappelan Damm, Oslo 2007.

Dahle G., Nyhus S., Sinna mann, Cappelan Damm, Oslo 2003.

Dahle G., Nyhus S., Snill, Cappelan Damm, Oslo 2002.

Dahle G., Nyhus S., Włosy mamy, przeł. H. Garczyńska, EneDueRabe, Gdańsk 2010.

Dahle G., Nyhus S., Zły Pan, przeł. P. Urbanik, EneDueRabe, Gdańsk 2013.

Nyhus S., Tato!, przeł. H. Garczyńska, EneDueRabe, Gdańsk 2008.

\section{Opracowania}

Bachelard G., Poetyka przestrzeni: szuflada, kufry i szafy, przeł. W. Krzemień, „Pamiętnik Literacki" 1976, z. 1.

Beckett S., Crossover Picturebooks. A Genre for All Ages, Routledge, New York-London 2012.

Bjorvand A.M., Do Sons Inherit the Sins of Their Fathers? An Analysis of the Picturebook Angry Man, [w:] New Directions in Picturebook Research, red. T. Colomer, B. Kümmerling-Meibauer, C. Silva-Diaz Cecilia, Routledge, New York-London 2010.

Dahle G., Bilderböcker som lekplats, [w:] En fanfar för bilderboken, red. U. Rhedin, K. Oscar, L. Eriksson, Alfabeta, Stockholm 2013.

Doonan J., Looking at Pictures in Picturebooks, Thimble Press, Stround 1993.

Dymel-Trzebiatowska H., Niebo ma wiele imion. Śmierć w skandynawskich ksiązkach obrazkowych, [w:] Śmierć w literaturze dziecięcej i młodzieżowej, red. K. Slany, SBP, Warszawa 2018.

Dymel-Trzebiatowska H., "Talking containers". Visual heterotopias in the picturebooks illustrated by Svein Nyhus, „Folia Scandinavica Posnaniensia” 2018, nr 25.

Evans J., The legendary Klaus Flugge: Controversial picturebooks and their place in contemporary society, [w:] Challenging and Controversial. Creative and Critical Responses, red. J. Evans, Routledge, New York-London 2015.

Karrebæk D., Oscar K., Världen rinner bort, [w:] En fanfar för bilderboken, red. U. Rhedin, K. Oscar, L. Eriksson, Alfabeta, Stockholm 2013.

Lakoff G., Johnson M., Metafory z naszym życiu, przeł. T.P. Kreszowski, Wydawnictwo Aletheia, Warszawa 2010.

Nikolajeva M., Scott C., How Picturebooks Work, Routledge, New York-London 2006.

Ommundsen A., Who Are these Picturebooks for?, [w:] Challenging and Controversial. Creative and Critical Responses, red. J. Evans, Routledge, New York-London 2015.

\section{Źródła internetowe}

Krogstad A., The family house chronotope in three picturebooks by Gro Dahle and Svein Nyhus: idyll, fantasy, and threshold experiences, „Barnelitterært Forskningstidsskrift” 2016, nr 7, https://www.tandfonline.com/doi/full/10.3402/blft.v7.26040. 


\title{
How to tell children about everything: The power of metaphor in the Norwegian picturebook Blekkspruten by Gro Dahle and Svein Nyhus
}

\begin{abstract}
Summary
The article discusses how the taboo theme of incest is narrated both visually and verbally in the controversial Norwegian picturebook Blekkspruten (The Squid) from 2016, authored by the famous Norwegian artists Gro Dahle, a writer, and Svein Nyhus, an illustrator. The duo had previously tackled numerous contentious themes in their books, such as domestic abuse, gender disparity and mental illness, but this time the subject seems particularly problematic to present in a children's book. Since both Dahle and Nyhus explicitly advocate a concept of allalderlitteratur (literature for all age groups), the implied readership of Blekkspruten includes young, inexperienced readers, too. The analysis focused on the mode in which the artists acquainted children with incest, and the answer was the intricate metaphorical message rendered both in the text and in the images. Their pregnant, yet subtle imagery and sophisticated interaction made it possible to narrate the difficult, challenging theme for children. Furthermore, the investigation responds to Dorte Karrebæk's suggestion to devote more reflection to the illustrators' work as a continuum. It juxtaposes Nyhus' illustrations from Blekkspruten with his previous works, showing both his new artistic solutions (different lines, shapes and colours) and references to some visual symbols employed before (open or closed containers, a monkey toy, a key). They recur in an intervisual, self-referential play, often participating in construction of open endings and implying the impossibility of giving unequivocal answers.
\end{abstract}

